\title{
Interaction between breeding habitat and elevation affects prevalence but not infection intensity of Batrachochytrium dendrobatidis in Brazilian anuran assemblages
}

\author{
Michael C. Gründler ${ }^{1}$, Luís Felipe Toledo ${ }^{2}$, Gabriela Parra-Olea ${ }^{3}$, \\ Célio F. B. Haddad ${ }^{4}$, Luis O. M. Giasson ${ }^{4}$, Ricardo J. Sawaya ${ }^{5}$, Cynthia P. A. Prado ${ }^{6}$, \\ Olívia G. S. Araujo ${ }^{4}$, Fernando J. Zara ${ }^{7}$, Fernanda C. Centeno ${ }^{4}$, Kelly R. Zamudio ${ }^{1, *}$ \\ ${ }^{1}$ Cornell University, Department of Ecology and Evolutionary Biology, Ithaca, New York 14853-2701, USA \\ ${ }^{2}$ Museu de Zoologia 'Prof. Dr. Adão José Cardoso', Universidade Estadual de Campinas, Campinas, São Paulo 13083-863, Brazil \\ ${ }^{3}$ Instituto de Biología, Universidad Nacional Autónoma de México, Distrito Federal 04510, Mexico \\ ${ }^{4}$ Departamento de Zoologia, Universidade Estadual Paulista, Rio Claro, São Paulo 13506-970, Brazil \\ ${ }^{5}$ Departamento de Ciências Biológicas, Universidade Federal de São Paulo, Diadema, São Paulo 09972-270, Brazil \\ ${ }^{6}$ Departamento de Morfologia e Fisiologia Animal, Universidade Estadual Paulista, Jaboticabal, São Paulo 14884-900, Brazil \\ ${ }^{7}$ Departamento de Biologia Aplicada, Universidade Estadual Paulista, Jaboticabal, São Paulo 14884-900, Brazil
}

\begin{abstract}
Chytridiomycosis, an infectious disease of amphibians, is caused by the fungus Batrachochytrium dendrobatidis $(B d)$ and has been linked to declining amphibian populations worldwide. The susceptibility of amphibians to chytridiomycosis-induced population declines is potentially influenced by many factors, including environmental characteristics, differences among host species and the growth of the pathogen itself. We investigated the effects of elevation and breeding habitat on $B d$ prevalence and individual infection intensity (zoospore loads) in 3 anuran assemblages of the Atlantic Coastal Forest of Brazil. $B d$ infection intensity was strongly influenced by elevation and breeding habitat, but we found no evidence of an interaction between those 2 variables in explaining the number of zoospores sampled from individual frogs. In contrast, $B d$ infection odds were predicted by elevation and by an interaction between elevation and breeding habitat, such that frogs had a higher probability of $B d$ infection in lotic habitats at low elevations. Our results indicate that $B d$ persists across a wide variety of habitats and elevations in the Atlantic Coastal Forest. Prevalence and infection intensity of $B d$ are highest at high elevations where overall environmental conditions for $B d$ are most favorable. In addition, at low elevations amphibian host habitat choice is also an important determinant of infection. Our study highlights the need to investigate interacting variables of host ecology and the environment simultaneously.
\end{abstract}

KEY WORDS: Frog $\cdot$ Chytridiomycosis $\cdot$ Atlantic Coastal Forest

Resale or republication not permitted without written consent of the publisher

\section{INTRODUCTION}

Chytridiomycosis, an emerging infectious disease caused by the fungus Batrachochytrium dendrobatidis $(B d)$, has been linked to declines of amphibian populations worldwide (Daszak et al. 2003, Skerratt et al. 2007, Lips et al. 2008). Whether specific amphibian species are susceptible to chytridiomycosis depends on the interaction between host ecology, $B d$ biology and characteristics of the environment (Daszak et al. 1999). Studies investigating correlates of $B d$ prevalence and amphibian population declines have 
implicated numerous environmental factors such as substrate, temperature, seasonality, degree of deforestation and elevation (Lips et al. 2003, Berger et al. 2004, Bosch et al. 2007, Raffel et al. 2010, Walker et al. 2010, Becker \& Zamudio 2011, Savage et al. 2011), as well as intrinsic characteristics of amphibian hosts such as breeding habitat, dependency upon aquatic environments, behavior, population size and immunity (Daszak et al. 2003, Lips et al. 2003, Woodhams et al. 2003, 2006, 2007, Kriger \& Hero 2007, Rowley \& Alford 2007, Richmond et al. 2009, Ramsey et al. 2010). Environmental conditions clearly affect pathogen proliferation and survival (Woodhams et al. 2003, Berger et al. 2004, Woodhams \& Alford 2005, Piotrowski et al. 2004, Drew et al. 2006, Walker et al. 2010); thus, it is especially important to understand how host and environmental factors interact to determine the impacts of $B d$ on species and communities (Fisher et al. 2009b, Briggs et al. 2010, Kilpatrick et al. 2010).

In tropical habitats, the most dramatic amphibian declines have occurred in montane, stream-dwelling frogs (Laurance et al. 1996, Berger et al. 1998, 1999, Lips 1999, Lips et al. 2003, La Marca et al. 2005). Bd grows best at cool temperatures and in wet conditions, so these observations are consistent with known $B d$ biology (Piotrowski et al. 2004). Brem \& Lips (2008) recently characterized the prevalence of $B d$ in tropical frog communities at epizootic and enzootic stages and showed that prevalence is mediated by a complex interaction between environmental characteristics, species identity and the density of populations at various disease stages and in different habitats. At sites where amphibian hosts persist and $B d$ is enzootic, prevalence of the pathogen should be lower and infected individuals should have relatively low $B d$ infection intensities (Briggs et al. 2010), rarely reaching lethal levels typically observed during epizootic outbreaks (Vredenburg et al. 2010). At enzootic sites, reservoirs for the pathogen, such as infected species or life stages with low disease susceptibility, or persistence of pathogen in the environment will permit continual re-infection of surviving individuals in the population (Briggs et al. 2010). These predictions underscore the need for a more detailed understanding of the interactions that possibly control infection dynamics in highly diverse tropical frog communities (Kilpatrick et al. 2010). Studies of $B d$ prevalence in tropical regions where the disease is not epizootic, but where populations still persist at relatively high densities, can further our understanding of how environment-host interactions affect $B d$ prevalence and intensity of infection in natural populations.
The Brazilian Atlantic Coastal Forest (ACF) is a biodiversity hotspot and harbors a diverse endemic amphibian fauna (Mittermeier et al. 1998). This biome is threatened because of continuing habitat disturbance and forest fragmentation that has reduced forest cover to less than $16 \%$ of its original extent (Ribeiro et al. 2009). To date, approximately 25 frog species have tested positive for $B d$ in Brazil, and those species were found throughout the entire north-south distribution of the ACF (Carnaval et al. 2006, Toledo et al. 2006a,b, Sluys et al. 2007, Becker \& Zamudio 2011, Vieira et al. in press). A survey of museum specimens identified 1981 as an upper boundary for the earliest appearance date of $B d$ in this biome (Carnaval et al. 2006), a timeframe coincident with qualitative reports of species extinctions and community declines at the few sites from which historical data are available (Heyer et al. 1988, Weygoldt 1989, Eterovick et al. 2005). Although these demographic declines have not been attributed specifically to chytridiomycosis outbreaks, the widespread distribution of $B d$ in the ACF has led to the general assumption that $B d$ is enzootic there and that the diverse assemblage of amphibian species in this region maintain populations despite the continued presence of the pathogen.

In this study we quantified the odds and severity of $B d$ infection in 3 distinct anuran assemblages endemic to the Brazilian ACF and explicitly tested the interaction between amphibian breeding habitat and elevation, 2 important predictors of $B d$ prevalence and infection intensity in amphibian populations (Berger et al. 2004, Lips et al. 2006, Rachowicz et al. 2006, Kriger \& Hero 2007, Brem \& Lips 2008, Walker et al. 2010). Specifically, we addressed the following questions: (1) to what extent do elevation and breeding habitat affect the odds and severity of $B d$ infection in highly diverse tropical frog communities, and (2) is there a significant interaction between these 2 variables? Understanding the dynamics of $B d$ infection in this region provides a comparative framework for studies of chytridiomycosis in regions where $B d$ is epizootic. Furthermore, baseline data on the ecology and epidemiology in this region may become useful in the event of future $B d$ outbreaks.

\section{MATERIALS AND METHODS}

\section{Sampling localities and methods}

We chose $3 \mathrm{ACF}$ sites in the Brazilian states of São Paulo and Minas Gerais (Fig. 1, Table 1). To minimize latitudinal bias, we chose sites within a narrow latitu- 


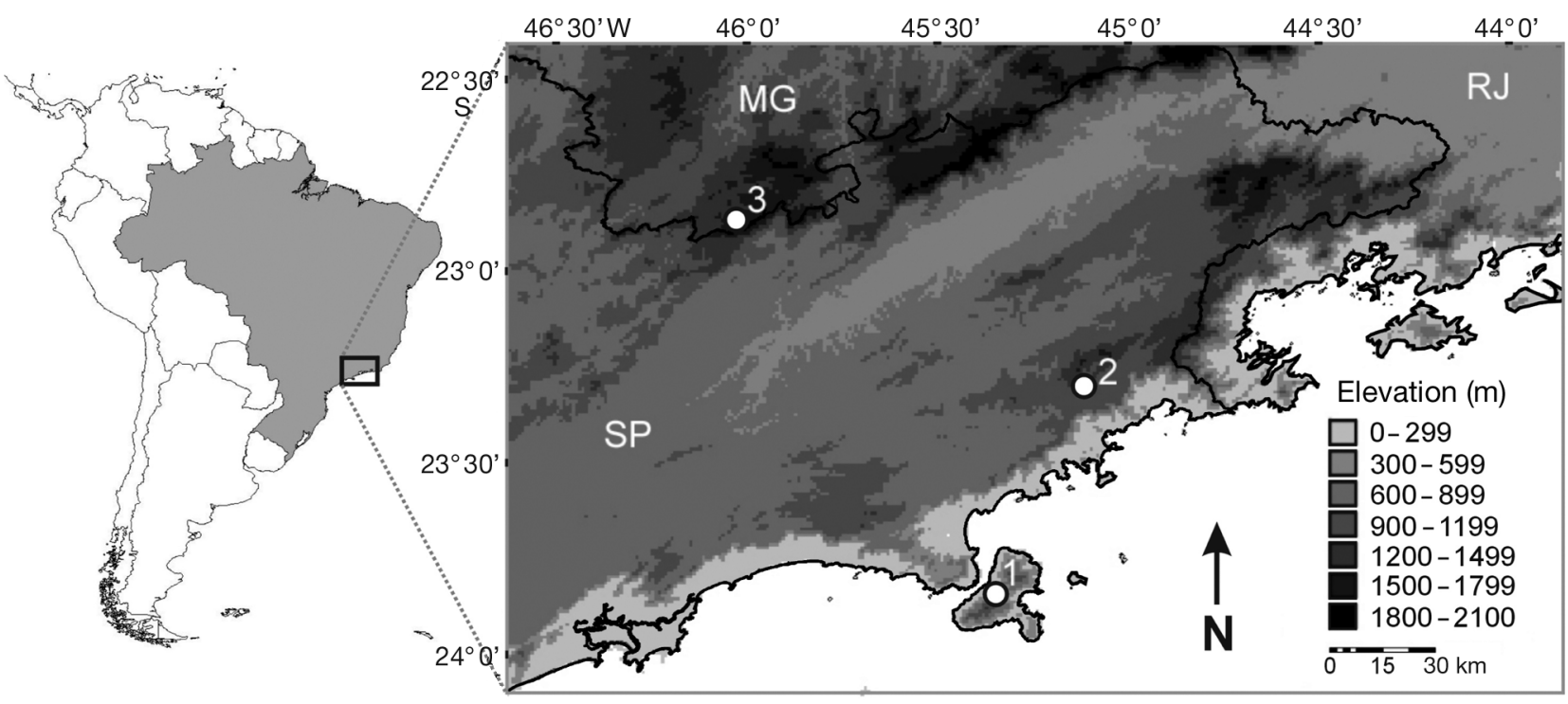

Fig. 1. Location of 3 amphibian sampling sites in southeastern Brazil: Ilhabela (1), Santa Virginia (2), and Monte Verde (3). Letters refer to the Brazilian states of São Paulo (SP), Rio de Janeiro (RJ), and Minas Gerais (MG)

Table 1. Location and climatic characteristics at the 3 sites sampled for this study. Bioclimatic variables were extracted using Worldclim/Bioclim layers (1000 m resolution; Hijmans et al. 2005). Temperature and precipitation are averaged from 50 yr records (1950-2000) from a global network of climatic stations. WQ: wettest quarter of the year

\begin{tabular}{|c|c|c|c|c|c|c|}
\hline \multirow[t]{2}{*}{ Locality } & \multirow{2}{*}{$\begin{array}{l}\text { Latitude, } \\
\text { longitude }\end{array}$} & \multirow{2}{*}{$\begin{array}{l}\text { Elevation } \\
(\mathrm{m})\end{array}$} & \multicolumn{2}{|c|}{ Mean temperature $\left({ }^{\circ} \mathrm{C}\right)$} & \multicolumn{2}{|c|}{ Precipitation $(\mathrm{mm})$} \\
\hline & & & Annual & WQ & Annual & WQ \\
\hline Ilhabela & $23^{\circ} 48^{\prime} \mathrm{S}, 45^{\circ} 22^{\prime} \mathrm{W}$ & $0-100$ & 23.1 & 25.9 & 1667 & 727 \\
\hline Sta. Virginia & $23^{\circ} 17^{\prime} \mathrm{S}, 45^{\circ} 6^{\prime} \mathrm{W}$ & 1000 & 16.2 & 18.7 & 1692 & 791 \\
\hline Monte Verde & $22^{\circ} 51^{\prime} \mathrm{S}, 46^{\circ} 1^{\prime} \mathrm{W}$ & 1600 & 13.8 & 16.3 & 1869 & 883 \\
\hline
\end{tabular}

dinal band of less than 1 arcminute. We sampled frog populations from 3 sites spanning the elevational range of the ACF: a low elevation site on the Ilha de São Sebastião, municipality of Ilhabela, state of São Paulo (hereafter Ilhabela); a mid-elevation site within the Núcleo Santa Virginia of the Parque Estadual da Serra do Mar, municipality of São Luís do Paraitinga, state of São Paulo (hereafter Santa Virginia); and a high elevation site, Monte Verde, municipality of Camanducaia, state of Minas Gerais. The 3 focal sites differ significantly in elevation as well as temperature and precipitation (Table 1), yet all sites show a pattern typical for the region of a warmer wet season during the austral summer. All frogs included in our study were captured in closed canopy forests. Amphibian community composition changes rapidly with elevation in the $\mathrm{ACF}$, making it impossible to sample the same species of frogs at each site; instead, our analysis focused on $B d$ infection dynamics at the community level at each elevation, and compared groups of frogs breeding in similar environments.
At each site we sampled frogs that breed in 3 different habitat types: lentic (standing water), lotic (flowing water) and terrestrial (Table 2). The one exception was our high elevation site, Monte Verde, where terrestrially breeding frogs are not as common, and thus were not sampled. Because we were testing the effect of breeding habitat on $B d$ dynamics, we sampled only frogs that were actively breeding during the sampling period. Breeding habitat may represent only a small portion of the habitat used in an individual's life and $B d$ exposure is known to be high in non-breeding environments (Cossel \& Lindquist 2009) and during drier nonbreeding seasons (Longo et al. 2010). Thus, our sampling does not capture important annual or seasonal variation that might affect $B d$ infection dynamics in this system, and reflects only the prevalence and load during the season these species are reproductively active.

Frogs were captured in the field and individually maintained in clean, unused plastic bags. All frogs 
Table 2. Frogs species sampled, breeding habitat, Batrachochytrium dendrobatidis $(B d)$ prevalence (\% individuals infected) per locality and $B d$ infection intensity (mean zoospores $\pm \mathrm{SD}$ ) of infected individuals. $N_{\mathrm{i}}=$ number of infected frogs, $N_{\mathrm{s}}=$ number of sampled frogs. Bold numbers represent mean infection intensity $( \pm$ SD) for all frogs at that locality

\begin{tabular}{|c|c|c|c|c|c|}
\hline Species & Habitat & $N_{\mathrm{i}}$ & $N_{\mathrm{s}}$ & Prevalence (\%) & Intensity (zoospores) \\
\hline \multicolumn{6}{|l|}{ Ilhabela } \\
\hline Bokermannohyla hylax & Lotic & 2 & 5 & 40.0 & $25.42 \pm 23.78$ \\
\hline Cycloramphus boraceiensis & Lotic & 3 & 17 & 17.6 & $17.14 \pm 20.17$ \\
\hline Dendropsophus berthalutzae & Lentic & 0 & 15 & 0 & - \\
\hline Haddadus binotatus & Terrestrial & 1 & 16 & 6.3 & 41283 \\
\hline Hylodes asper & Lotic & 3 & 16 & 18.8 & $20.91 \pm 14.55$ \\
\hline Hylodes phyllodes & Lotic & 4 & 19 & 21.1 & $192.38 \pm 368.85$ \\
\hline Hypsiboas albomarginatus & Lentic & 0 & 16 & 0 & - \\
\hline Leptodactylus marmoratus & Terrestrial & 1 & 19 & 5.3 & 12.13 \\
\hline Scinax hayii & Lentic & 1 & 18 & 5.6 & 108.48 \\
\hline Thoropa taophora & Lotic & 6 & 24 & 25 & $\begin{aligned} 225.48 & \pm 258.32 \\
\mathbf{2 0 8 0 . 5 3} & \pm \mathbf{8 9 8 5 . 0 3}\end{aligned}$ \\
\hline \multicolumn{6}{|l|}{ Santa Virginia } \\
\hline Aplastodiscus leucopygius & Lotic & 3 & 8 & 37.5 & $226.45 \pm 322.14$ \\
\hline Bokermannohyla circumdata & Lentic & 9 & 15 & 60.0 & $121.51 \pm 160.29$ \\
\hline Bokermannohyla hylax & Lotic & 6 & 12 & 50.0 & $72.40 \pm 120.80$ \\
\hline Dendropsophus microps & Lentic & 4 & 13 & 30.8 & $71.18 \pm 109.06$ \\
\hline Dendropsophus minutus & Lentic & 2 & 14 & 14.3 & $24.91 \pm 27.67$ \\
\hline Flectonotus ohausi & Terrestrial & 2 & 14 & 14.3 & $58.60 \pm 80.50$ \\
\hline Hylodes phyllodes & Lotic & 2 & 10 & 20.0 & $112.67 \pm 155.64$ \\
\hline Hypsiboas faber & Lentic & 2 & 15 & 13.3 & $40.56 \pm 37.22$ \\
\hline Hypsiboas pardalis & Lentic & 7 & 9 & 77.8 & $359.67 \pm 662.42$ \\
\hline Hypsiboas polytaenius & Lentic & 0 & 9 & 0 & - \\
\hline Ischnocnema guentheri & Terrestrial & 9 & 11 & 81.8 & $\begin{array}{r}2951.61 \pm 5969.84 \\
\mathbf{6 9 6 . 6 9} \pm \mathbf{2 7 7 1 . 5 3}\end{array}$ \\
\hline \multicolumn{6}{|l|}{ Monte Verde } \\
\hline Aplastodiscus callipygius & Lotic & 9 & 12 & 75.0 & $13141.54 \pm 38962.74$ \\
\hline Aplastodiscus perviridis & Lentic & 12 & 13 & 92.3 & $1127.08 \pm 2201.87$ \\
\hline Bokermannohyla luctuosa & Lentic & 15 & 20 & 75.0 & $5595.33 \pm 10576.53$ \\
\hline Dendropsophus microps & Lentic & 9 & 15 & 60.0 & $577.31 \pm 1007.52$ \\
\hline Hylodes magalhaesi & Lotic & 3 & 6 & 50.0 & $2.55 \pm 1.41$ \\
\hline Hypsiboas latistriatus & Lotic & 11 & 20 & 55.0 & $302.41 \pm 449.21$ \\
\hline Hypsiboas prasinus & Lentic & 10 & 15 & 66.7 & $\begin{array}{l}3539.00 \pm 3731.17 \\
\mathbf{3 7 6 3 . 0 2} \pm \mathbf{1 4 8 9 7 . 1 7}\end{array}$ \\
\hline
\end{tabular}

were captured and handled using non-powdered latex gloves to prevent sample cross-contamination. To control for the potential confounding effects of body size and life stage (Lamirande \& Nichols 2002) we targeted adult frogs and sampled all 3 localities during the same rainy season (between late September 2006 and early January 2007). Each frog was sampled for $B d$ infection using sterile cotton swabs run over the body of each animal in a standardized fashion. The frogs were held upside down and the same swab was used for 30 strokes, targeting the pelvic region and limbs of the animal. We swabbed each frog 5 times along both the right and left undersides of the upper thighs/flanks, and 5 times along the underside of the digits on the front and hind feet, including the webbed area between the toes. We sampled skin swabs from 396 frogs and 25 distinct species across all 3 localities. The swabs were preserved in Eppendorf tubes containing 100\% ethanol and maintained in a refrigerator until the samples were returned to the laboratory for $B d$ quantification. The majority of frogs were released at their site of capture. We humanely euthanized a subset of sampled animals and deposited preserved specimens in the Coleção de Anuros (CFBH), Departamento de Zoologia, Universidade Estadual Paulista, Rio Claro, São Paulo, Brazil (Table 3), as vouchers for this study.

\section{Molecular detection methods}

We followed the extraction protocol of Boyle et al. (2004) with the following changes: (1) swabs were stored in ethanol, which we evaporated in a vacuum 
Table 3. Voucher specimens deposited at the Coleção de Anuros (CFBH) anuran collection, Departamento de Zoologia, Universidade Estadual Paulista, Rio Claro, São Paulo, Brazil

\begin{tabular}{|lc|}
\hline Location & Voucher no. \\
\hline $\begin{array}{l}\text { Monte Verde, Municipality of } \\
\text { Camanducaia, Minas Gerais State }\end{array}$ & CFBH 17582-17613 \\
Parque Estadual Serra do Mar, Núcleo & CFBH 14651-14660; \\
Santa Virginia, Municipality of São & $14770-14811 ; 14817-14876$ \\
Luís do Paraitinga, São Paulo State & \\
Ilha de São Sebastião, Municipality of & CFBH 15076-15160; 15172-15212; \\
Ilhabela, São Paulo State & $15220-15344 ; 15393-15432$ \\
\hline
\end{tabular}

centrifuge at room temperature prior to extraction; and (2) we extracted DNA using a higher volume $(160 \mu \mathrm{l})$ of PrepMan Ultra, because we used larger swabs (Boyle et al. 2004, Hyatt et al. 2007). We used a 1:10 dilution of the extract as template in quantitative (real-time) Taqman polymerase chain reaction (PCR) assays for the detection of $B d$ (Boyle et al. 2004). This assay uses the species-specific primers ITS1-3 Chytr and 5.8S Chytr in addition to the fluorescently labeled probe Chytr MGB2 to amplify a fragment of the $B d$ genome at the junction of the ITS-1 and 5.8S regions. DNA standards were diluted to give 1000, 100, 10, 1 and 0.1 zoospore genome equivalents for use in the Taqman assay following PCR conditions described in Boyle et al. (2004). Each sample was run in duplicate, and samples were identified as positive only if clear amplification with a change in fluorescence was observed in both runs and the estimated number of genomic equivalents in each run was greater than 1 (Kriger et al. 2007). The numbers of zoospore genomic equivalents recovered from the skin swab assays for each frog are reported as infection intensity and represent the severity of individual $B d$ infection. Mean infection intensities for different sites or habitats were estimated as the mean zoospore loads of infected frogs in each group (i.e. excluding frogs with zero zoospore loads). We estimated the prevalence of $B d$ within each anuran assemblage as the number of frogs that tested positive for $B d$ divided by the total number of frogs sampled at that site.

\section{Analyses of $\boldsymbol{B d}$ infection intensity}

We used 1-way ANOVA to test for differences in $B d$ infection intensity between different breeding habitats and elevations. Because residuals were not normally distributed, we log transformed zoospore loads to meet assumptions of parametric tests. We used a Student's $t$-test for post hoc pairwise comparisons between habitat and elevation categories. To further test for interaction between breeding habitat and elevation, we used a standard least squares linear regression in the statistical package JMP 7.1 (SAS 2007). We treated breeding habitat and elevation as fixed effects and species as a nested random effect. Treating species as a random effect allows us to test for differences among habitat and elevation (the main predictors of interest), while accounting for the fact that we could not sample the same complement of species at each locality. To determine whether differences in infection intensity among species accounted for a significant proportion of the total variation, we ran a model excluding the random effect of species identity and used a likelihood ratio test to determine whether this model fit the data better than the full model with this term included. We then ran the best-fit model without an interaction term between breeding habitat and elevation because no frogs sampled from Monte Verde were terrestrial breeders, making our design unbalanced. To test for an interaction we used 2 submodels that accounted for the missing comparisons. The first model included all 3 elevational sites and 2 habitat categories (excluding the terrestrial habitat), and the second model included 2 elevational sites (excluding Monte Verde) and all 3 breeding habitat categories.

\section{Analyses of $B d$ infection odds}

We used $B d$ infection status (presence/absence) data for each frog to model the odds of $B d$ infection for frogs breeding in different habitats and at different elevations using generalized linear models with a logit link function in the $\mathrm{R}$ programming environment. As in the analysis of infection intensity, we compared models for infection state that included and excluded species identity as a random effect, and used Akaike's information criterion (AIC) to evaluate relative model fit. We then ran the full best-fit model without an interaction term between breeding habitat and elevation and tested for interaction using 2 sub-models to account for the lack of terrestrial breeders at our highest elevation site. 


\section{RESULTS}

We sampled 7 to 11 species of frogs from each of our 3 focal sites. Eight of 10 species were infected at the lowest elevation $(100 \mathrm{~m}), 10$ of 11 species were infected at the middle elevation $(1000 \mathrm{~m})$ and all 7 species were infected at the highest elevation $(1600 \mathrm{~m}) . B d$ prevalence within species ranged from 0 to $40 \%$ at the lowest elevation, 0 to $77.8 \%$ at the middle elevation and 50.0 to $92.3 \%$ at the highest elevation site. Infection intensity was highly variable and individual loads ranged from 1.32 to 17881.60 zoospores at the lowest elevation, 25 to 2952 zoospores at the middle elevation, and 1.05 to 117040 zoospores at the highest elevation (Table 2).

\section{$B d$ infection intensity}

One-way ANOVA showed that, in isolation, both breeding habitat and elevation had a significant effect on infection intensity (Fig. 2); however, both variables explained only a small fraction of the variation in the data (elevation: $\mathrm{r}^{2}=0.091, F_{2,133}=6.8262$, $\mathrm{p}=0.0015$; habitat: $\mathrm{r}^{2}=0.085, F_{2,133}=6.1480, \mathrm{p}=$ 0.0028). Mean infection intensity (considering only infected frogs) was most severe at the highest elevation site (mean log zoospores $=5.38$ ), intermediate at the mid-elevation site (mean log zoospores $=3.83$ ) and least severe at the low elevation site (mean log zoospores $=3.70$ ), with a significant difference in infection intensity between the high elevation site and the other 2 sites (low elevation, $t=2.69, \mathrm{p}=$ 0.0081 and mid elevation, $t=-3.24, \mathrm{p}=0.0015)$. Mean infection intensity was significantly higher in both lentic breeding species (mean log zoospores = 5.18) and terrestrial breeding species (mean log zoospores $=5.28)$ compared with lotic breeding species (mean log zoospores $=3.63)(t=-3.35, \mathrm{p}=0.0010$ and $t=2.11, \mathrm{p}=0.0371$, respectively).

The likelihood-ratio test (LRT) showed that the full model including species identity as a random effect was not a better fit to the data than the full model without this effect (LRT $=0.272, \mathrm{df}=1, \mathrm{p}>0.05$ ), and that species identity accounted for only $12.4 \%$ of the variance in infection intensity. The full model excluding the interaction term and the random species effect was highly significant $(F=7.54$, df $=4$, p < 0.0001), and elevation and breeding habitat were significant predictors of infection intensity (Table 4). No significant interaction term between breeding habitat and elevation was found for either sub-model (Table 4, Fig. 3).

\section{Bd infection odds}

We compared models for individual $B d$ infection status including and excluding species identity as a random effect. The model including a random effect of species was a better fit to our data $(\mathrm{AIC}=419.2$ and 429.03 with and without species, respectively), indi-
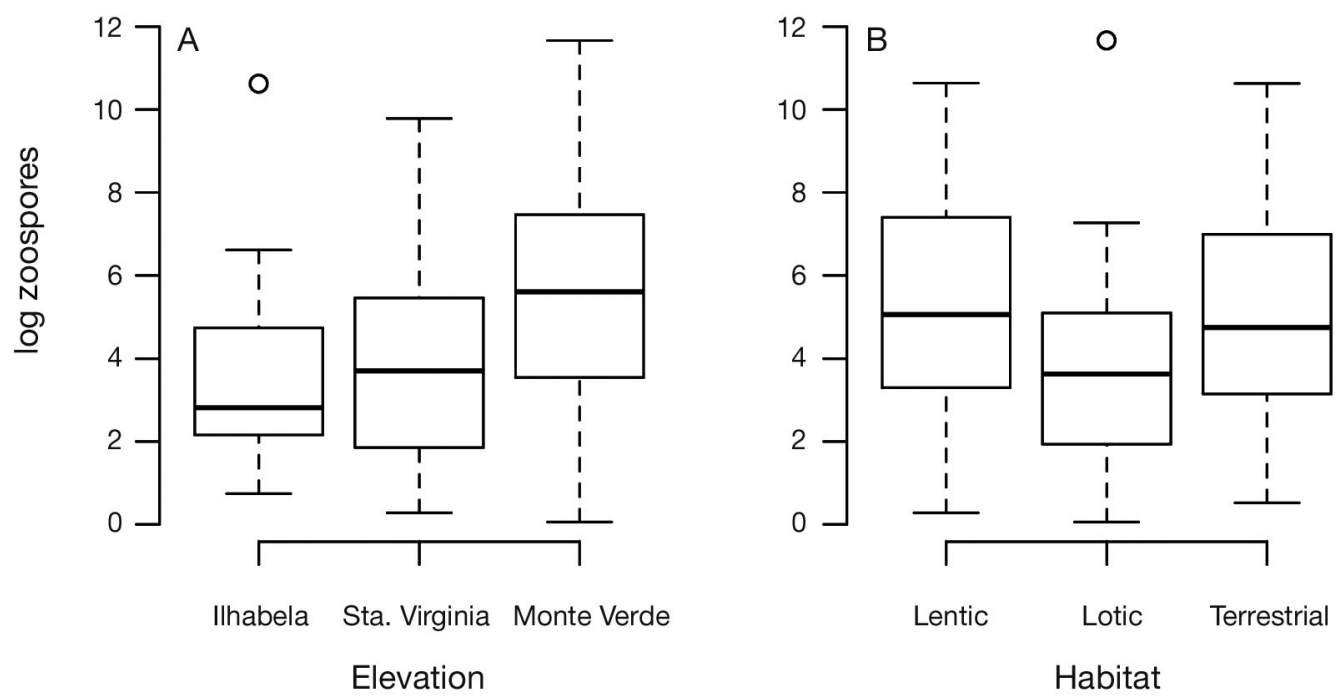

Fig. 2. Variation in Batrachochytrium dendrobatidis $(B d)$ infection intensity across (A) elevation and (B) breeding habitats. Top and bottom of boxplots represent the 75th and 25th percentiles, respectively; bold lines within boxes indicate medians. Whiskers connect the maximum and minimum values within the interquartile range; isolated points: infection intensities outlying the interquartile range 
Table 4. Least square regression examining the effects of elevation and habitat and their interaction on Batrachochytrium dendrobatidis infection intensity in Brazilian frog populations. The best-fit model includes 3 habitat types and 3 elevations, but does not include species as a random effect. Submodels test for habitat by elevation interactions on prevalence by examining only 2 habitats or 2 elevations. $\mathrm{p}$-values for significant variables in each model are highlighted in bold

\begin{tabular}{|c|c|c|c|c|}
\hline Effect & df & SS & $F$ & $\mathrm{p}$ \\
\hline \multicolumn{5}{|c|}{ Best-fit model (no interactions) } \\
\hline Elevation & 2 & 94.76 & 8.26 & 0.0004 \\
\hline Habitat & 2 & 86.93 & 7.58 & 0.0008 \\
\hline \multicolumn{5}{|c|}{ Submodel 1 (3 elevations/2 habitats) } \\
\hline Elevation & 2 & 54.31 & 5.11 & 0.007 \\
\hline Habitat & 1 & 10.25 & 1.93 & 0.167 \\
\hline Elevation $\times$ Habitat & 2 & 17.04 & 1.60 & 0.205 \\
\hline \multicolumn{5}{|c|}{ Submodel 2 (3 habitats/2 elevations) } \\
\hline Elevation & 1 & 4.07 & 0.84 & 0.363 \\
\hline Habitat & 2 & 33.70 & 3.47 & 0.037 \\
\hline Elevation $\times$ Habitat & 2 & 3.73 & 0.38 & 0.682 \\
\hline
\end{tabular}

cating that among-species differences in infection odds account for a significant proportion of variation in the data. In the model excluding any interaction term, but including the random effect of species, elevation was the only significant predictor of $B d$ infection (Table 5) and the odds of infection increased consistently with elevation (Fig. 4). We found a significant interaction between breeding habitat and elevation for both sub-models (Table 5). This was driven by significant differences in the odds of infection among breeding habitats at low elevations, where lotic breeding frogs were significantly more likely to harbor $B d$ infections. No significant differences among breeding habitats were seen at higher elevations (Fig. 4).

\section{DISCUSSION}

We found cases of high $B d$ prevalence and infection intensity in many species, habitats and at all elevations, corroborating earlier findings that this pathogen is ubiquitously distributed in this threatened biome (Carnaval et al. 2006, Toledo et al. 2006a). The epidemiology of $B d$ in the ACF is enigmatic. Despite widespread documented $B d$ occurrence and climatic suitability for $B d$ (Ron 2005, Fisher et al. 2009b), the rapid and large-scale amphibian faunal declines observed at other Neotropical sites have not been evident there (Pimenta et al. 2005). Arrival of $B d$ at upland sites in Costa Rica and Panama is typically accompanied by extinctions of up to $50 \%$ of species and $80 \%$ reductions in overall amphibian abundances (Lips et al. 2006, Brem \& Lips 2008). In the Brazilian ACF we have documented historical declines or extinctions of 31 species (Heyer et al. 1988, Eterovick et al. 2005), but those represent only a small fraction of the amphibian diversity $(6 \%$ of the 510 frog species in the ACF; F. Toledo unpubl. data), and observed declines are localized to particular sites or regions (Heyer et al. 1988, Eterovick et al. 2005). Historical quantitative data on species abun-
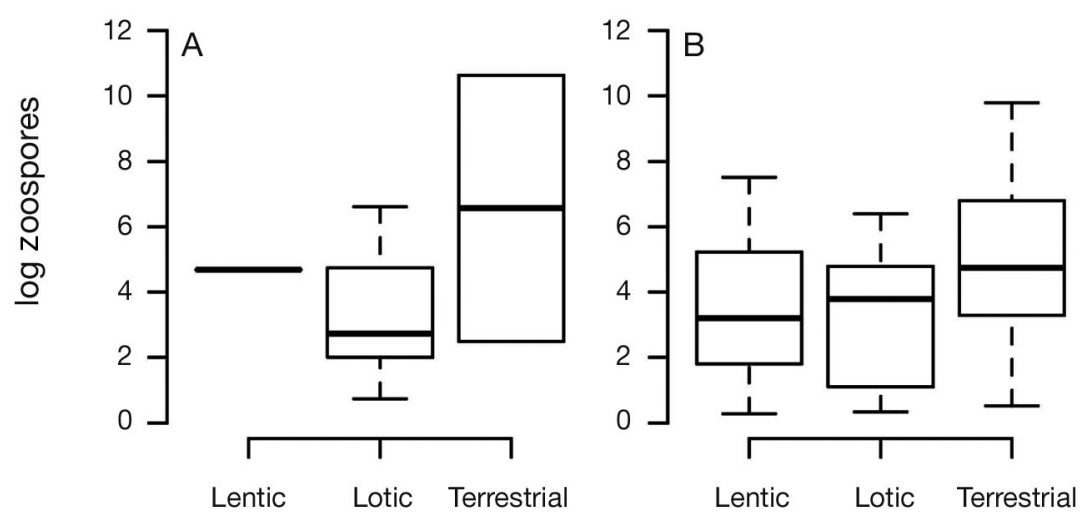

Habitat

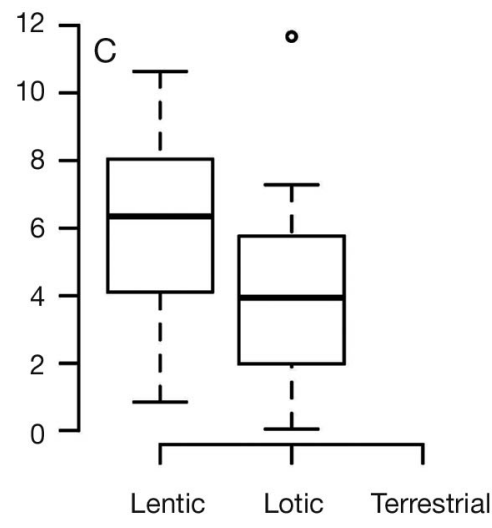

Fig. 3. Batrachochytrium dendrobatidis $(B d)$ infection intensity for breeding habitats partitioned by site showing broad overlap in variation. (A) Ilhabela $(100 \mathrm{~m}) ;$ (B) Santa Virginia $(1000 \mathrm{~m}) ;(\mathrm{C})$ Monte Verde $(1600 \mathrm{~m})$. A single infected individual was found for the lentic category and 2 infected individuals were found for the terrestrial category in Ilhabela. No significant interaction between breeding habitat and elevation was found for either submodel (see 'Results'). Other box and whisker plot details as in Fig. 2 
Table 5. General linear model coefficients for the effects of elevation and habitat and their interaction on Batrachochytrium dendrobatidis infection presence/absence in Brazilian frog populations. The best-fit model includes 3 habitat types and 3 elevations as fixed effects, and species identity as a random effect. Submodels test for habitat by elevation interactions on prevalence by examining only 2 habitats or 2 elevations. $p$-values for significant variables in each model are highlighted in bold

\begin{tabular}{|lcccc|}
\hline & Estimate & SE & $z$ & $\mathrm{p}$ \\
\hline Best-fit model (no interactions) & & & & \\
Intercept & -2.328 & 0.4694 & -4.96 & $<\mathbf{0 . 0 0 1}$ \\
Habitat (stream) & 0.56 & 0.4727 & 1.185 & 0.2362 \\
Habitat (terrestrial) & 0.2021 & 0.6491 & 0.311 & 0.7555 \\
Elevation (1600 m) & 2.7292 & 0.4981 & 5.48 & $<\mathbf{0 . 0 0 1}$ \\
Elevation (1000 m) & 1.3711 & 0.435 & 3.152 & $\mathbf{0 . 0 0 1 6}$ \\
Submodel 1 (3 elevations/2 habitats) & & & & \\
(Intercept) & -3.973 & 1.086 & -3.657 & $<\mathbf{0 . 0 0 1}$ \\
Habitat (stream) & 2.734 & 1.139 & 2.4 & $\mathbf{0 . 0 1 6 4}$ \\
Elevation (1600 m) & 4.848 & 1.144 & 4.238 & $<\mathbf{0 . 0 0 1}$ \\
Elevation (1000 m) & 3.242 & 1.13 & 2.868 & $\mathbf{0 . 0 0 4 1}$ \\
Habitat (stream) $\times$ Elevation (1600 m) & -3.156 & 1.271 & -2.482 & $\mathbf{0 . 0 1 3 1}$ \\
Submodel 2 (3 habitats/2 elevations) & & & & \\
(Intercept) & -4.1483 & 1.2074 & -3.436 & $<\mathbf{0 . 0 0 1}$ \\
Habitat (stream) & 2.9309 & 1.286 & 2.279 & $\mathbf{0 . 0 2 2 7}$ \\
Habitat (terrestrial) & 1.1713 & 1.5347 & 0.763 & 0.4453 \\
Elevation (1000 m) & 3.2798 & 1.2787 & 2.565 & $\mathbf{0 . 0 1 0 3}$ \\
Habitat (stream) $\times$ Elevation (1000 m) & -2.8067 & 1.4064 & -1.996 & $\mathbf{0 . 0 4 6 0}$ \\
\hline
\end{tabular}

those 2 variables (breeding habitat and elevation). In contrast, infection odds varied significantly with elevation, but differed among breeding habitats only at the lowest elevation, with a higher probability of infection in frogs breeding in low-elevation streams. These results underscore the different nature of prevalence and infection intensity as measures of $B d$ dynamics and suggest that distinct mechanisms are controlling these 2 parameters.

\section{$B d$ infection intensity}

Our results indicate a relationship between elevation, breeding habitat and $B d$ infection intensity. We did not find a pattern of continuous increase in infection intensity with elevation; rather, we found a significant increase in infection intensity only at the highest elevation site and no evidence of an interaction between amphibian breeding habitat and ele-

dance do not exist for most ACF amphibian communities (Stuart et al. 2004, Pimenta et al. 2005); thus, some of these differences may be explained by declines or extinctions that have gone undetected. Alternatively, it is possible that $B d$ exists in the ACF as a less-lethal pathogen (Daszak et al. 2003, Fisher et al. 2009a, Farrer et al. 2011) or that the climatic conditions favoring its emergence are not prevailing in the ACF (Bosch et al. 2007, Rohr \& Raffel 2010). A pattern of heterogeneous disease outcomes despite the widespread occurrence of $B d$ has been documented for populations of Alytes obstetricans in Iberia (Walker et al. 2010), emphasizing the context dependence of chytridiomycosis outbreaks. Clearly, further studies of $B d$ infection dynamics and pathogen-host interactions are necessary to better understand the impact $B d$ has had and may still have on the ACF amphibian fauna.

Breeding habitat and elevation have independently been implicated as determinants of prevalence and severity of $B d$ infection in amphibian populations (Lips et al. 2003, Kriger \& Hero 2007, Brem \& Lips 2008, Walker et al. 2010). We found that $B d$ infection intensities were highest in lentic and terrestrial breeding habitats and at the high elevation site, but we found no significant interaction between vation. In addition, $B d$ infection intensity was highest in frogs with lentic and terrestrial breeding habitats. Most comparative studies to date show that the amphibian species most severely impacted by $B d$ live or breed in streams (Laurance et al. 1996, Lips 1999, Lips et al. 2003), and this correlation is most pronounced during epizootic phases of chytridiomycosis outbreaks (Brem \& Lips 2008). We expected the greatest intensity of infection to be among our stream-dwelling anurans. Contrary to this expectation, lotic breeding frogs in our study had the lowest mean infection intensity across all elevations. This may be due to larger $B d$ and/or frog populations in ponds and puddles compared with stream environments (Brem \& Lips 2008); however, we lack direct estimates of $B d$ abundance from environmental sources (Piotrowski et al. 2004, Lips et al. 2006) or estimates of host population densities at our sites. A second unexpected result from our finding was that terrestrially breeding frogs showed infection intensities comparable to aquatic-breeding frogs. $B d$ persists best in wet, humid environments and is unable to survive prolonged desiccation (Johnson et al. 2003, Piotrowski et al. 2004), which could protect terrestrial breeders from high rates of $B d$ infection. Our results show that $B d$ may be more resistant to non-optimal 

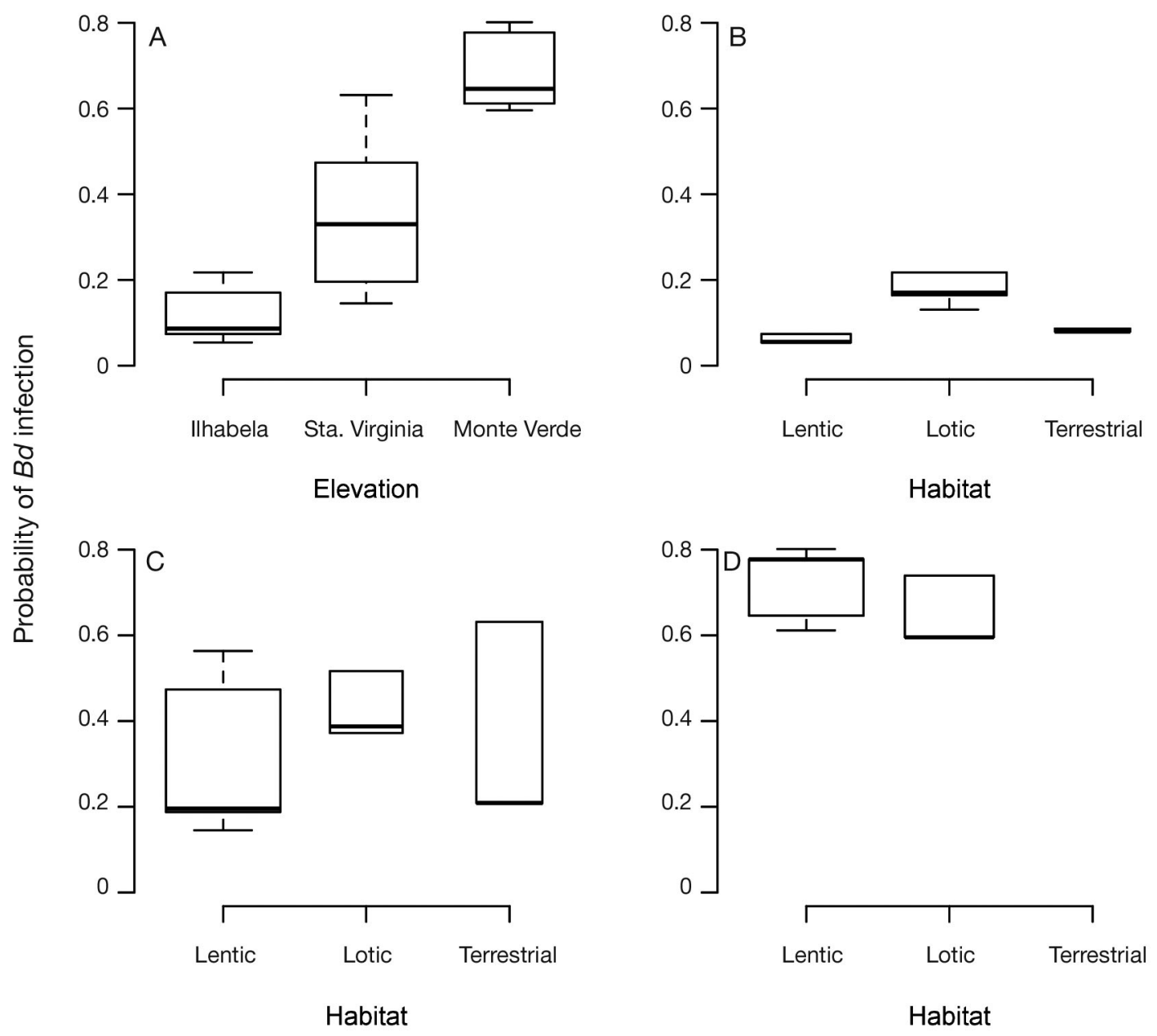

Fig. 4. Estimated probability of Batrachochytrium dendrobatidis (Bd) infection by (A) elevation and (B-D) breeding habitat: (B) Ilhabela $(100 \mathrm{~m}),(\mathrm{C})$ Santa Virginia $(1000 \mathrm{~m})$ and (D) Monte Verde $(1600 \mathrm{~m})$. The change in rank order of breeding habitats across elevations reflects the significant interaction between breeding habitats and elevation. Lotic breeding frogs had significantly higher probability of infection at the lowest elevation (B), but no significant differences among breeding habitats were observed at higher elevations. Other box and whisker plot details as in Fig. 2

environmental conditions than laboratory studies suggest and persists in terrestrial environments. A recent study documented the presence of $B d$ in water from bromeliads, with higher zoospore counts from these terrestrial water sources than from lotic water sources (Cossel \& Lindquist 2009). Frog-to-frog transmission following occasional contact with these and other terrestrial reservoirs may play an important role in infection of terrestrial breeding frogs (Parris \& Cornelius 2004, Kriger \& Hero 2007, Rowley \& Alford 2007). In fact, the 2 species of frogs from the low and middle elevations with the highest infection intensities are terrestrial breeding direct-developers of the Terrarana clade (Table 2). At epizootic Neotropical sites, terrestrial direct-developing frogs are more likely to survive $B d$-induced amphibian community declines (Lips et al. 2003, 2006), and at enzootic sites in Central and South America and in the Caribbean, direct developing lineages persist with high $B d$ infection intensities (Longo \& Burrowes 2010, Longo et al. 2010). The 4 terrestrial breeding frogs in our sample had either comparable (Leptodactylus marmoratus, Flectonotus ohausi) or relatively high (Haddadus binotatus, Ischnocnema guentheri) infection intensities compared with aquatic breeding species at mid and high elevations (Table 2). This pattern could change with the inclusion of more terrestrial breeders, as only 2 species from this class were sampled at each site. However, this initial observation of high infection intensity confirms that at least some species of terrestrial breeders come in frequent contact with $B d$ and can carry high infection intensities, making them potential reservoirs for $B d$ in $\mathrm{ACF}$ as well (Longo et al. 2010). 


\section{$B d$ prevalence}

In contrast to infection intensity, our data on infection odds showed a significant and continuous increase with elevation, a common pattern in amphibian communities (Laurance et al. 1996, Lips 1999, Lips et al. 2003, 2008). Furthermore, we found a significant interaction between breeding habitat and elevation in the model explaining $B d$ prevalence. At the lowest elevation, lotic breeding frogs had higher $B d$ infection odds than frogs breeding in either lentic or terrestrial habitats. This effect was not evident at high elevations, where frogs from all breeding habitats were equally likely to be infected with $B d$. Two other studies to date have documented non-random distribution of $B d$ across breeding habitats (Kriger \& Hero 2007, Brem \& Lips 2008). Our data indicate further that habitat differences might be accentuated at the lowest elevations, where the environmental conditions are outside the optimal physiological thresholds of $B d$ (Piotrowski et al. 2004) and thus pathogen fitness is expected to be sub-optimal.

We found high infection intensities and infection odds for each habitat type at high elevation, indicating that environmental variation relevant to $B d$ growth across breeding habitats is relatively small at sites where environmental conditions for $B d$ growth are within the optimal range (Piotrowski et al. 2004). At low elevations, infection intensites were quite similar across breeding habitats, and higher infection intensity did not correlate with higher $B d$ prevalence. These patterns should be interpreted with a few caveats in mind. First, we do not know how our sampled species vary in resistance to chytridiomycosis and therefore cannot assess whether our collections may have been biased to more resistant species at lower elevations. Second, it is possible that the observed patterns could change with refinement of our broad breeding habitat classifications. For example, many terrestrial breeding anurans actually breed in small standing water pockets (hollow stems, bromeliads, tree holes, etc.) that function as lentic habitats. Our sample sizes prevented making these finer distinctions, but we know of diversity in reproductive modes even among the 4 terrestrial species we sampled: Haddadus binotatus and Ischnocnema guentheri lay egg clutches on the surface of moist soil, under logs and leaf litter and eggs undergo direct development; Leptodactylus marmoratus constructs subterranean chambers where tadpoles develop in a foam nest; and Flectonotus ohausi carry their eggs on the female's dorsum and deposit endotrophic tad- poles in water-filled cavities of bamboo stems for development (Haddad \& Prado 2005). These differences could play a role in shaping site-specific patterns of $B d$ prevalence and infection intensity.

\section{Other determinants of $\boldsymbol{B d}$ infection dynamics}

We found predictive associations between breeding habitat and elevation for $B d$ infection intensity and odds, despite variance in many other environmental characteristics directly related to $B d$ growth that were not included in our study (e.g. temperature, humidity). Kriger \& Hero (2007), in a study of $B d$ dynamics across multiple habitats, showed that although stream-breeding frogs have a higher prevalence of $B d$ than pond or terrestrial breeding frogs, mean infection intensity did not differ significantly between habitats (Kriger \& Hero 2007). Our data suggest additional complexity. If optimal environmental conditions for $B d$ are the main determinant of infection dynamics, we would expect our data to show a consistent increase in $B d$ infection intensity at higher elevation sites (as was seen for infection odds). We also would expect a better correspondence between infection intensity and odds for breeding habitats at the lowest elevation. The fact that these patterns were not evident in our data underscores the difference between infection prevalence (a population variable) and infection intensity (an individual condition). $B d$ infection dynamics within an individual host consist of complicated interactions between demographic, environmental and individual processes; thus, environmental conditions favorable to pathogen growth are certainly not the only determinants of pathogen dynamics (Andre et al. 2008, Murray et al. 2009, Walker et al. 2010). We are just beginning to understand how individual variation in behavior, activity pattern, microhabitat selection and immunogenetic variability mediate susceptibility to infection (Andre et al. 2008, Longo et al. 2010, Richards-Zawacki 2010, Richmond et al. 2009). Our observation that only a small (and non-significant) component of variation in infection intensity is explained by differences among species in the full statistical model (Table 4) implies that much of the variation may be occurring at the individual level.

Our study examined a potential interaction between amphibian host biology and environmental characteristics, and extends the ecological work on $B d$ to a new Neotropical region with different infection dynamics. Further comparative studies are necessary to assess the generality of $B d$ epidemiology in 
the Neotropics and, specifically, the interplay among individual and population variation and local dynamics of $B d$. As with any emergent infectious disease, future conservation endeavors will need to take into account the possible interactions between species biology and environmental conditions to ensure the persistence of amphibian biodiversity (Kilpatrick et al. 2010).

Acknowledgements. We thank Laura Marquez for laboratory assistance; Fausto Barbo, Murilo Rodrigues and Roberto Nomura for field assistance; David Zeber, Francoise Vermeylen (Cornell Statistical Consulting Unit), Joe Simonis, C. Guilherme Becker, and Diego Ruiz-Moreno for help with statistical analysis; George Rabb for supporting the quantitative PCR workshop at Universidad Nacional Autónoma de México (UNAM); and the Zamudio Lab for constructive comments on earlier versions of the manuscript. The Research and Analysis Network for Amphibians (NSF DEB0139273) and UC-MEXUS (Award no. 022043) funded laboratory analyses; field collection efforts were funded by grants and fellowships from CNPq, FAPESP and a Biotic Survey and Inventory Grant from the National Science Foundation.

\section{LITERATURE CITED}

Andre SE, Parker J, Briggs CJ (2008) Effect of temperature on host response to Batrachochytrium dendrobatidis infection in the mountain yellow-legged frog (Rana muscosa). J Wildl Dis 44:716-720

Becker CG, Zamudio KR (2011) Tropical amphibian populations experience higher disease risk in natural habitats. Proc Natl Acad Sci USA 108:9893-9898

Berger L, Speare R, Daszak P, Green DE and others (1998) Chytridiomycosis causes amphibian mortality associated with population declines in the rain forests of Australia and Central America. Proc Natl Acad Sci USA 95: 9031-9036

Berger L, Speare R, Hyatt A (1999) Chytrid fungi and amphibian declines: overview, implications, and future directions. In: Campbell A (ed) Declines and disappearances of Australian frogs. Environment Australia, Canberra, p 23-33

Berger L, Speare R, Hines HB, Marantelli G and others (2004) Effect of season and temperature on mortality in amphibians due to chytridiomycosis. Aust Vet J 82:31-36

Bosch J, Carrascal LM, Duran L, Walker S, Fisher MC (2007) Climate change and outbreaks of amphibian chytridiomycosis in a montane area of Central Spain; is there a link? Proc Biol Sci 274:253-260

Boyle DG, Boyle DB, Olsen V, Morgan JAT, Hyatt AD (2004) Rapid quantitative detection of chytridiomycosis (Batrachochytrium dendrobatidis) in amphibian samples using real-time Taqman PCR assay. Dis Aquat Org 60:141-148

Brem FMR, Lips KR (2008) Batrachochytrium dendrobatidis infection patterns among Panamanian amphibian species, habitats and elevations during epizootic and enzootic stages. Dis Aquat Org 81:189-202

Briggs CJ, Knapp RA, Vredenburg VT (2010) Enzootic and epizootic dynamics of the chytrid fungla pathogen of amphibians. Proc Natl Acad Sci USA 107:9695-9700

Carnaval ACOQ, Puschendorf R, Peixoto OL, Verdade VK, Rodríguez MT (2006) Amphibian chytrid fungus broadly distributed in the Brazilian Atlantic rain forest. EcoHealth 3:41-48

Cossel JO, Lindquist ED (2009) Batrachochytrium dendrobatidis in arboreal and lotic water sources in Panama. Herp Rev 40:45-47

> Daszak P, Berger L, Cunningham AA, Hyatt AD, Green DE, Speare R (1999) Emerging infectious diseases and amphibian population declines. Emerg Infect Dis 5:735-748

Daszak P, Cunningham AA, Hyatt AD (2003) Infectious disease and amphibian population declines. Divers Distrib 9: $141-150$

Drew A, Allen EJ, Allen LJS (2006) Analysis of climate and geographic factors affecting the presence of chytridiomycosis in Australia. Dis Aquat Org 68:245-250

Eterovick PC, Carnaval ACOQ, Borges-Nojosa DM, Silvano DL, Segalla MV, Sazima I (2005) Amphibian declines in Brazil: an overview. Biotropica 37:166-179

Farrer RA, Weinert LA, Bielby J, Garner TWJ and others (2011) Multiple emergences of genetically diverse amphibian infecting chytrids include a globalized hypervirulent recombinant lineage. Proc Natl Acad Sci USA 108:18732-18736

- Fisher MC, Bosch J, Yin Z, Stead D and others (2009a) Proteomic and phenotypic profiling of the amphibian pathogen Batrachochytrium dendrobatidis shows that genotype is linked to virulence. Mol Ecol 18:415-429

> Fisher MC, Garner TWJ, Walker SF (2009b) Global emergence of Batrachochytrium dendrobatidis and amphibian chytridiomycosis in space, time, and host. Annu Rev Microbiol 63:291-310

- Haddad CFB, Prado CPA (2005) Reproductive modes in frogs and their unexpected diversity in the Atlantic forest of Brazil. Bioscience 55:207-217

> Heyer WR, Rand AS, da Cruz CAG, Peixoto OL (1988) Decimations, extinctions, and colonizations of frog populations in southeast Brazil and their evolutionary implications. Biotropica 20:230-235

> Hijmans RJ, Cameron SE, Parra JL, Jones PG, Jarvis A (2005) Very high resolution interpolated climate surfaces for global land areas. Int J Climatol 25:1965-1978

- Hyatt AD, Boyle DG, Olsen V, Boyle DB and others (2007) Diagnostic assays and sampling protocols for the detection of Batrachochytrium dendrobatidis. Dis Aquat Org 73: 175-192

> Johnson ML, Berger L, Philips L, Speare R (2003) Fungicidal effects of chemical disinfectants, UV light, desiccation and heat on the amphibian chytrid Batrachochytrium dendrobatidis. Dis Aquat Org 57:255-260

Kilpatrick AM, Briggs CJ, Daszak P (2010) The ecology and impact of chytridiomycosis: an emerging infectious disease of amphibians. Trends Ecol Evol 25:109-118

Kriger KM, Hero JM (2007) The chytrid fungus Batrachochytrium dendrobatidis is non-randomly distributed across amphibian breeding habitats. Divers Distrib 13: 781-788

Kriger KM, Ashton KJ, Hines BH, Hero JM (2007) On the biological relevance of a single Batrachochytrium dendrobatidis zoospore: a reply to Smith. Dis Aquat Org 73:257-260

> La Marca E, Lips KR, Lötters S, Puschendorf R and others (2005) Catastrophic population declines and extinctions in Neotropical harlequin frogs (Bufonidae: Atelopus). Biotropica 37:190-201

Lamirande EW, Nichols DK (2002) Effects of host age on susceptibility to cutaneous chytridiomycosis in blue-and-yellow poison dart frogs (Dendrobates tinctorius). In: McKinnell RG, Carlson DL (eds) Proceedings of the Sixth International Symposium on the Pathology of Reptiles and 
Amphibians. University of Minnesota Printing Services, Saint Paul, MN, p 3-13

Laurance WF, McDonald KR, Speare R (1996) Epidemic disease and the catastrophic decline of Australian rain forest frogs. Conserv Biol 10:406-413

Lips KR (1999) Mass mortality and population declines of anurans at an upland site in western Panama. Conserv Biol 13: $117-125$

Lips KR, Reeve JD, Witters LR (2003) Ecological traits predicting amphibian population declines in Central America. Conserv Biol 17:1078-1088

Lips KR, Brem F, Brenes R, Reeve JD and others (2006) Emerging infectious disease and the loss of biodiversity in a Neotropical amphibian community. Proc Natl Acad Sci USA 103:3165-3170

> Lips KR, Diffendorfer J, Mendelson JR, Sears MW (2008) Riding the wave: reconciling the roles of disease and climate change in amphibian declines. PLoS Biol 6:e72

> Longo AV, Burrowes PA (2010) Persistence with chytridiomycosis does not assure survival of direct-developing frogs. EcoHealth 7:185-195

> Longo AV, Burrowes PA, Joglar RL (2010) Seasonality of Batrachochytrium dendrobatidis infection in direct-developing frogs suggests a mechanism for persistence. Dis Aquat Org 92:253-260

Mittermeier RA, Myers N, Thomsen JB, da Fonseca GAB, Olivieri S (1998) Biodiversity hotspots and major tropical wilderness areas: approaches to setting conservation priorities. Conserv Biol 12:516-520

> Murray KA, Skerrat LF, Speare R, McCallum H (2009) Impact and dynamics of disease in species threatened by the amphibian chytrid fungus, Batrachochytrium dendrobatidis. Conserv Biol 23:1242-1252

Parris MJ, Cornelius TO (2004) Fungal pathogen causes competitive and developmental stress in larval amphibian communities. Ecology 85:3385-3395

Pimenta BVS, Haddad CFB, Nascimento LB, Cruz CAG, Pombal JP Jr (2005) Comment on 'status and trends of amphibian declines and extinctions worldwide'. Science 309:1999

Piotrowski JS, Annis SL, Longcore JE (2004) Physiology of Batrachochytrium dendrobatidis, a chytrid pathogen of amphibians. Mycologia 96:9-15

Rachowicz LJ, Knapp RA, Morgan JAT, Stice MJ, Vredenburg VT, Parker JM, Briggs CJ (2006) Emerging infectious disease as a proximate cause of amphibian mass mortality. Ecology 87:1671-1683

Raffel TR, Michel PJ, Sites EW, Rohr JR (2010) What drives chytrid infections in newt populations? Associations with substrate, temperature, and shade. EcoHealth 7:526-236

Ramsey JP, Reinert LK, Harper LK, Woodhams DC, RollinsSmith LA (2010) Immune defenses against Batrachochytrium dendrobatidis, a fungus linked to global amphibian declines, in the South African clawed frog, Xenopus laevis. Infect Immun 78:3981-3992

Ribeiro MC, Metzger JP, Martensen AC, Ponzoni FJ, Hirotac MM (2009) The Brazilian Atlantic Forest: How much is left, and how is the remaining forest distributed? Implications for conservation. Biol Conserv 142:1141-1153

Richards-Zawacki CL (2010) Thermoregulatory behaviour affects prevalence of chytrid fungal infection in a wild population of Panamanian golden frogs. Proc Biol Sci 277: 519-528

Richmond JQ, Savage AE, Rosenblum EB, Zamudio KR (2009) Toward immunogenetic studies of amphibian declines: linking innate and acquired immunity. Bioscience 59: 311-320

Rohr JR, Raffel TR (2010) Linking global climate and temperature variability to widespread amphibian declines putatively caused by disease. Proc Natl Acad Sci USA 107 : 8269-8274

> Ron SR (2005) Distribution of the amphibian pathogen Batrachochytrium dendrobatidis in the New World: insights from niche models. Biotropica 37:209-221

Rowley JJL, Alford RA (2007) Behaviour of Australian rainforest stream frogs may affect the transmission of chytridiomycosis. Dis Aquat Org 77:1-9

SAS (2007) JMP Version 7. SAS Institute, Inc., Cary, NC

Savage AE, Zamudio KR, Sredl M (2011) Disease dynamics vary spatially and temporally in a North American amphibian. Biol Conserv 144:1910-1915

Skerratt LF, Berger L, Speare R, Cashins S and others (2007) Spread of chytridiomycosis has caused the rapid global decline and extinction of frogs. EcoHealth 4:125-134

Slys MV, Ferreria TK, Lamarão FRM, Moraes MO (2007). Batrachochytrium dendrobatidis infects Melanoprhyniscus moreirae (Anura Bufonidae) from an Atlantic rainforest area (Itatiaia), southeastern Brazil. Froglog 84:6-7

Stuart SN, Chanson JS, Cox NA, Young BE, Rodrigues ASL, Fischman DL, Waller RW (2004) Status and trends of amphibian declines and extinctions worldwide. Science 306:1783-1786

Toledo LF, Brito FB, Araújo OGS, Giasson LOM, Haddad CFB (2006a) The occurrence of Batrachochytrium dendrobatidis in Brazil and the inclusion of 17 new cases of infection. S Am J Herp 1:185-191

Toledo LF, Haddad CFB, Carnaval ACOQ, Britto FB (2006b) A Brazilian anuran (Hylodes magalhaesi: Leptodactylidae) infected by Batrachochytrium dendrobatidis: a conservation concern. Amphib Reptile Conserv 4:17-21

Vieira CA, Alameida CHLN, Lambertini C, Leite DS, Toledo LF (in press) First record of Batrachochytrium dendrobatidis in Paraná, Brazil. Herpetolog Rev

> Vredenburg VT, Knapp RA, Tunstall TS, Briggs CJ (2010) Dynamics of an emerging disease drive large-scale amphibian population extinctions. Proc Natl Acad Sci USA 107:9689-9694

Walker SF, Bosch J, Gomez V, Garner TWJ and others (2010) Factors driving pathogenicity versus prevalence of amphibian panzootic chytridiomycosis in Iberia. Ecol Lett 13: 372-382

Weygoldt P (1989) Changes in the composition of mountain stream frog communities in the Atlantic mountains of Brazil: frogs as indicators of environmental deteriorations? Stud Neotrop Fauna Environ 24:249-255

Woodhams DC, Alford RA (2005) Ecology of chytridiomycosis in rainforest stream frog assemblages of tropical Queensland. Conserv Biol 19:1449-1459

- Woodhams DC, Alford RA, Marantelli G (2003) Emerging disease of amphibians cured by elevated body temperature. Dis Aquat Org 55:65-67

> Woodhams DC, Voyles J, Lips KR, Carey C, Rollins-Smith LA (2006) Predicted disease susceptibility in a Panamanian amphibian assemblage based on skin peptide defenses. J Wildl Dis 42:207-218

> Woodhams DC, Vredenburg VT, Simon M, Billheimer D and others (2007) Symbiotic bacteria contribute to innate immune defenses of the threatened mountain yellowlegged frog, Rana muscosa. Biol Conserv 138:390-398

Submitted: December 11, 2009; Accepted: September 13, 2011 Proofs received from author(s): November 30, 2011 